\title{
Epithelial Cell Count
}

National Cancer Institute

\section{Source}

National Cancer Institute. Epithelial Cell Count. NCI Thesaurus. Code C64605.

The determination of the number of epithelial cells in a sample. 